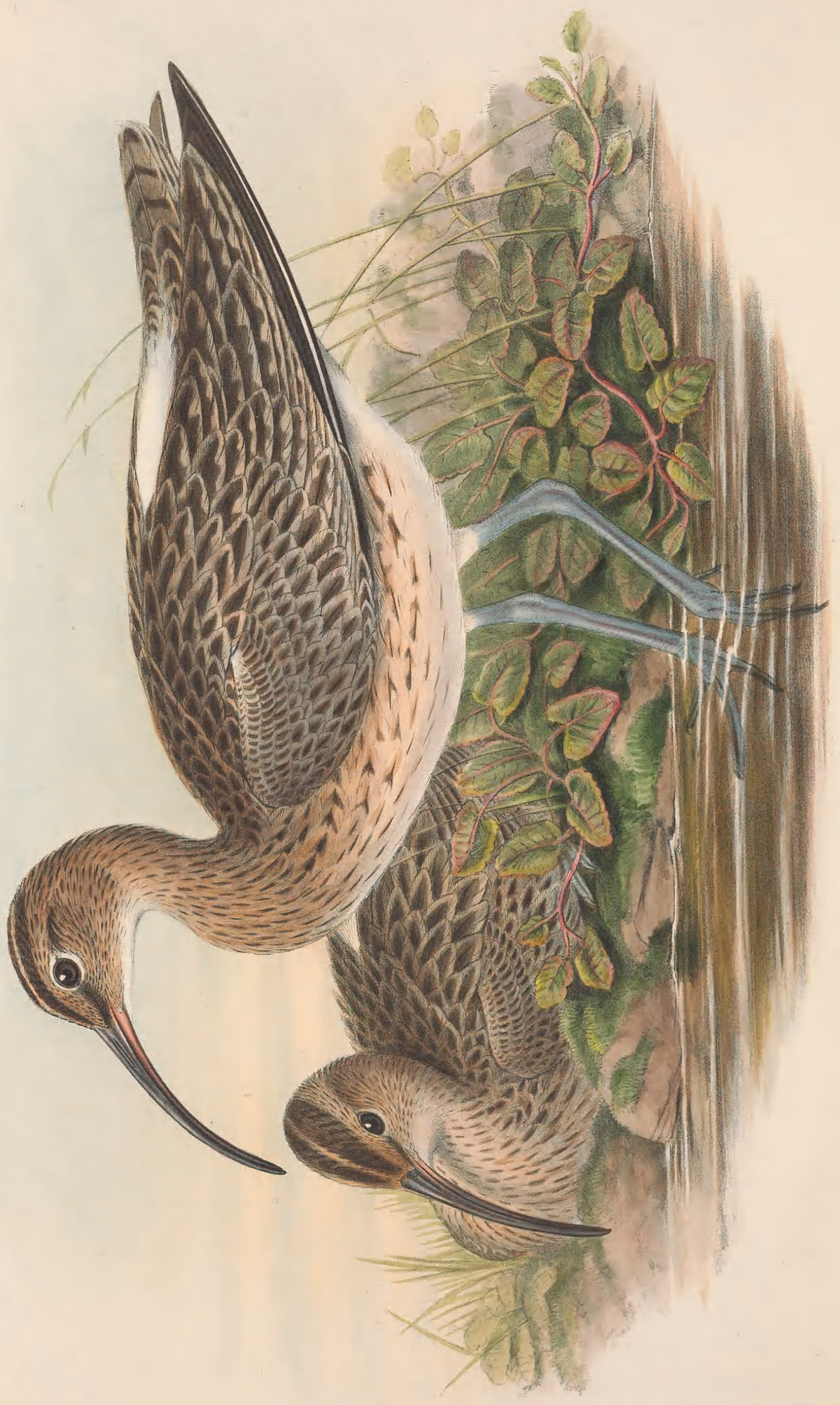

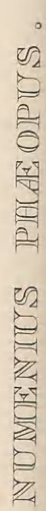




\title{
NUMENIUS PHAEOPU.
}

\section{Whimbrel.}

\author{
Scotopax phaopus, Linn. Faun. Suec., p. 60. \\ borealis, Gmel. edit. Linn. Syst. Nat., tom. i. p. 654. \\ Numenius pheopus, Lath. Ind. Orn., vol. ii. p. 711. \\ minor, Leach, Syst. Cat. of Indig. Mamm. and Birds in Coll. Brit. Mus., p. 32. \\ hudsonicus, Lath. Ind. Orn., vol. ii. p. 712 \\ islandicus, Brehm, Vög. Deutschl., p. 610 \\ Phcoopus arquatus, Steph. Cont. of Shaw's Gen. Zool., vol. xii. p. 36.
}

Whimbrels usually arrive in Eugland in the early part of May, and disperse themselves along our coasts, particularly those of the eastern counties; they are then on their passage northwards; but a few remain to breed on the moors of Scotland, and perhaps on those of the northern parts of England also; but if any nests be found in our southern counties, the circumstance must be regarded as quite exceptional. Still it cannot be denied that a few remain and winter with us. On the Continent, the high lands of Norway, Sweden, Lapland, and Iceland are, among others, favourite breeding-localities.

Its range over the Old World is very extensive; for, besides occurring in all parts of Europe, Mr. Edward Vernon Harcourt includes it in his 'List of the Birds of Madeira;' Mr. F. du Cane Godman states that it is occasionally met with on the coasts of the Azores; it is found all over Africa from north to south; according to $\mathrm{Mr}$. Jerdon it is very generally dispersed over India, and is supposed to go to Java, China, and Japan ; indeed its range is probably even still more extensive; but it is not found in America, neither does it frequent Australia.

Mr. Stevenson's account of the Whimbrel as observed by him in Norfolk being equally descriptive of the bird in other localities, I quote it in his own words :- "The Whimbrel visits us regularly in spring and autumn, on its passage to and from its breeding-grounds; and though a few may be seen occasionally in March or April, the appearance of the main body in May on the Breydon and Blakeney muds is so invariable that the species is always spoken of as the 'May-Bird' by the gunners in both localities. Their numbers, as with all migratory shore-birds, vary much in different seasons; but at times they are very plentiful, as was particularly the case in the spring of 1863. Of these, the chief portion pass on to the northward after a few days; but small parties may be seen on different parts of the coast up to the middle of June, and even as late as July. At Hunstanton, in 1863, I found one or two small flocks frequenting the mussel-scalps up to the second week in June; and Mr. Dowell has observed them at Blakeney, in two or three different seasons, between the 25 th and 30th of July, "not paired off, but keeping together in "herds" of from eight to ten,' most probably birds which would neither breed here nor elsewhere during that summer. By the end of August or beginning of September, old and young together have again commenced their southward journey; but the numbers then seen are but few in comparison with the spring flight. In Mr. Dowell's notes I find no mention of this bird having been observed by him at Blakeney later than the first week in October; and Mr. F. Frere describes them as always scarce in autumn at Breydon, and rarely, if ever, seen during the winter months. Mr. Lubbock speaks of this species as having been occasionally very numerous at Horsey, visiting the marshes in considerable flocks in April and May; and in describing the habits of the bird he says :- 'They are far more easy of access than the Curlews, and when disturbed make shorter flights, removing only from one marsh to another, instead of rising high in the air and forsaking the district altogether, as the Curlew generally does. They have a clattering coufused cry in flight, which baffles any imitation by the human voice.' This cry, however, according to Messrs. Sheppard and Whitear, resembles the sounds 'Weddy, tetty, tetty, tetty tet,' quickly repeated.'

In confirmation of his assertion that these birds are very plentiful at some seasons more than at others, Mr. Stevenson refers to Mr. Cordeaux's statement, in the 'Zoologist,' that a flock of at least two hundred appeared in the Humber district about the 3rd of May, and that on the 13th of May, 1868, he counted up to sixty-one in one flock, and saw another containing not less than double that number; and when speaking of their diminished numbers in autumn, he remarks that Mr. Cordeaux has noticed that in Lincolnshire, during the months of August and September 1866, the Whimbrels were seen in small parties, passing orerhead at a considerable height, constantly repeating their call-note and flying in a south or southwesterly direction. Mr. Cordeaux also states, from his observation of the bird in the same county, that the Whimbrel is far more of a land-bird than the Curlew, feeding almost exclusively in marshes, and 
retiring occasionally to the flats to rest and bathe, "being," adds Mr. Stevenson, "particularly fond of washing and splashing the water over their plumage with their wings."

"This is the only one of the Scolopacidæ," says Thompson, "which can be characterized in general terms as a bird of double passage, only visiting us merely on migration to and from its breeding-hauuts. In the month of April or May it appears in large flocks along the line of the eastern coast, on that of Wexford, Dublin, Louth, Down, Antrim, \&c. As the Whimbrel is not found to the westward within the latitude of Ireland, it is interesting to know that these migratory bodies move as regularly along the western as the eastern coast. Thus they are very common in April and May near Tralee, in Kerry, appear in large flocks about Roundstone, on the Galway coast, in May, and remain during that month where they are unknown at other times. They likewise take an inland course of flight, appearing, among other places, at the marshes below Killaloe, on the Shannon, every spring, and in the high moory ground about Lough Conn, in Mayo. Their popular name everywhere has the word May connected with it, as May-bird, May-fowl, \&c., in consequence of their appearance in that month. On their arrival in spring they are often very tame, and may be openly approached within gun-shot; but persecution soon makes them wild. They generally remain from four to six weeks, then depart, and reappear again very soon after the breeding-season, generally about the middle of July, their numbers gradually increasing from the time they are first seen. During August they are most numerous in the Bay of Belfast, from which they are chiefly gone by the end of September. In spring, Whimbrels generally keep by themselves; but in autumn they exhibit a very sociable disposition, and are frequently to be found in company with Curlews and Godwits. They fly much about during the autumnal nights, be they dark or moonlight, but prefer the latter. They may always be distinguished by their cry. They fly from the sea inland as well as the opposite direction, and take both courses during every turn of the tide; hence we may consider them to be night-feeding birds."

"In the beginning of May," says Macgillivray, "a few individuals of this species make their appearance here and there on the sandy pastures bordering the west coast of the long range of the Outer Hebrides, from one end to the other. Their numbers daily increase, until, in about a week, they are in many places very numerous. Their food consists of Bulimus acutus and Helix ericetorum, which are very abundant there. They walk, for the most part, sedately, but sometimes with alacrity, having their neck bent forward, and their regards fixed on the ground. If alarmed, they stand, elevate their heads, emit a shrill tremulous cry, and perhaps fly off, or presently resume their search. If surprised, they are clamorous in their flight, but usually alight at no great distance. When on the wing they display the white part of the back conspicuously, and have a beautiful appearance."

"The Whimbrel," remarks Mr. Hewitson, "breeds in wild, desolate districts, far distant from human habitation, on open moors and uncultivated wastes, choosing in preference those which are wet and marshy and composed of moss and that black peaty soil which is, in such places, a substitute for coal.

"The nest is nothing more than a slight depression in the surface of the ground. We might expect that the eggs, like those of all the allied species, would be four in number; but none of the nests I have myself examined contained more than three ; as these were all fresh, the number was probably incomplete."

The late Mr. Wolley informed Mr. Hewitson that "in the Faroe Islands the Whimbrel is very abundant, and is always flying round just out of shot; in the north of Sweden and Finland it is to be seen in most of the open marshes, and is very noisy, especially when sitting at the top of a tree or stake (for it also frequents places where there is a good deal of wood). Yet I have never happened to be present at the finding of more than two nests; they were little more than depressions in the ground, and contained each three eggs only." From this additional information we must come to the conclusion that the Whimbrel lays only three. The eggs are pear-shaped, very like those of the Curlew, but smaller, and are of a dark olive-brown, blotched with darker brown.

I am indebted to Mr. J. Edmund Harting for a fine example of this bird, killed by him on the 11th of May 1870, in Pagham Harbour, in Sussex, to which, he states, the bird is "a regular visitant in May and August," as he believes is the case along the whole of our south coasts. "In May, only the old birds are seen; in August, both old and young make their appearance. The young admit of a nearer approach than the old ones, and are good eating."

The birds in the accompanying Plate are about the size of life. 


\section{$2 \mathrm{BHL}$ Biodiversity Heritage Library}

Gould, John. 1873. "Whimbrel, Numenius phæopus [PI. 49]." The birds of Great Britain 4, -. https://doi.org/10.5962/p.324006.

View This Item Online: https://www.biodiversitylibrary.org/item/221609

DOI: https://doi.org/10.5962/p.324006

Permalink: https://www.biodiversitylibrary.org/partpdf/324006

\section{Holding Institution}

Smithsonian Libraries

\section{Sponsored by}

Biodiversity Heritage Library

\section{Copyright \& Reuse}

Copyright Status: Public domain. The BHL considers that this work is no longer under copyright protection.

This document was created from content at the Biodiversity Heritage Library, the world's largest open access digital library for biodiversity literature and archives. Visit BHL at https://www.biodiversitylibrary.org. 